\title{
REFLECTIONS ON THE RECENT HISTORIOGRAPHY OF EASTERN CONGO*
}

\author{
RENÉ LEMARCHAND
}

University of Florida

\begin{abstract}
Considering the scale of violence that has accompanied the crisis in eastern Congo, the avalanche of academic writings on the subject is hardly surprising. Whether it helps us better understand the region's tortured history is a matter of opinion. This critical article grapples with the contributions of the recent literature on what has been described as the deadliest conflict since the Second World War. The aim, in brief, is to reflect on the historical context of the crisis, examine its relation to the politics of neighboring states, identify and assess the theoretical vantage points from which it has been approached, and, in conclusion, sketch out promising new directions for further research by social scientists. A unifying question that runs throughout the recent literature on the eastern Congo is how might a functioning state be restored or how might civil society organizations serve as alternatives to such a state-but there is little unanimity in the answers.
\end{abstract}

\section{Key Words}

Democratic Republic of Congo, eastern Africa, historiography, war, violence, state.

History is the most dangerous product the chemistry of the intellect has ever concocted ... It sets people dreaming, it intoxicates them, spawns in them false memories, exaggerates their reflexes, keeps old wounds open, torments them in their repose, prompts them to delusions of grandeur or deliriums of persecution, and makes them bitter arrogant, unbearable and vain.

Paul Valéry, Regards sur le monde actuel

Les violations graves des droits de l'homme ne meurent jamais complètement. Les questions sans réponse et le chagrin qu'elles suscitent restent dans l'inconscient de celui qui a vécu ces évènements. Elles subsistent comme une douleur fantôme dans le corps de ceux qui viennent à la suite, leurs enfants et petits-enfants.

Luc Huyse, Tout passe, sauf le passé.

When I received an invitation from the editors of this journal to contribute a think-piece on the history and historiography of eastern Congo, my initial reaction was to decline the offer. Trained as a political scientist, I felt I would be somewhat out of my depth in taking up the assignment. Not that I am unacquainted with the bloodstained trajectory of the Great Lakes region; my doubts rather stemmed from the difficulties arising from the unyielding grip of conflicting imaginations on historical realities. Paul Valéry's jeremiads

* I gratefully acknowledge my indebtedness to Severine Autesserre, Lola Haskins, Marie-Eve Desrosiers, David Newbury, and Crawford Young for their judicious comments and criticisms whilst trying to rethink and revise earlier versions of this text. Author's email: renelemar@aol.com 
are a sobering reminder of how misperceptions of the past can mutate into tormenting delusions. ${ }^{\mathrm{I}}$ Connecting the dots between past and present is nowhere more fraught than where history is a violently contested terrain, where claims to citizenship are heavily determined by ideological constructions, and the tendrils of violence rooted in long ago events. In such a place, the boundary between fantasy and reality is subject to constant renegotiation. I am speaking here of the borderlands that separate the eastern marches of the Congo-known as Zaire from I97I to I997 and now the Democratic Republic of the Congo (DRC) - from its neighbors to the east, Uganda, Rwanda, and Burundi.

The latitude implicit in the notion of a think-piece eventually clinched my decision to throw disciplinary caution to the winds. Realizing, in retrospect, that much of my work on the Great Lakes region stands at the nexus of history, anthropology, and political science also helped. A further inducement relates to the length of my professional engagement in the study of the politics of the Congo: while few of my early works have stood the test of time, passing mention of their historical merits is perhaps not out of place in the context of this discussion. ${ }^{2}$ My early exposure to the political convulsions of the Great Lakes also accounts for what I have to admit is a somewhat subjective view of the phenomena discussed in this article: only by taking into account the longue durée dimension of the crisis can one gain a proper handle on the dynamics of the violence in eastern Congo. Only by reference to the huge refugee flows across boundaries, starting with the I959 Hutu revolution in Rwanda, can one properly grasp the scale of the human tragedies triggered by external interventions, and their political impact on host countries. Only by looking back at the legacy of the Mobutist state can one appreciate the historic roots of the issues facing its successor.

What follows, in brief, is a personal reflection on the historicity of the continuing crisis in eastern Congo seen through the prism of its recent historiography. How the region's tortured history has ripped apart the social fabric of its societies is not my only or primary concern; even more compelling is the need to understand how representations of the past by local actors and foreign observers alike may have helped to conjure up some of Valéry's demons.

Students of the region need not be reminded of the obvious: the historiography of eastern Congo is huge, and extremely diverse. It consists of hundreds of articles, essays, book chapters, reports by international non-governmental organizations (NGOs) and the United Nations (UN), and scores of books by scholars, journalists, and human rights activists. This discussion only deals with a fraction of the extant literature. In addition to the halfdozen books that form the overarching frame of this article, I have tried to give proper attention to a number of additional sources selected on the basis of their relevance to the issues raised. ${ }^{3}$ Some may quibble with this somewhat arbitrary triage. I readily concede

I The quote above is borrowed from J. Sémelin, Purify and Destroy: The Political Uses of Massacre and Genocide, trans. C. Schoch (London 2007), 23.

2 See my Political Awakening in the Congo (Berkeley, CA, I964) and Rwanda and Burundi (London, I970); for a comparative discussion of more recent developments in these states see The Dynamics of Violence in Central Africa (Philadelphia, 2009).

3 T. Turner, The Congo Wars: Conflict, Myth and Reality (London, 2007); F. Reyntjens, The Great African War: Congo and Regional Geopolitics, 1996-2006 (Cambridge, 2009); G. Prunier, Africa's 
that among the many contributions that have been left out, some deserve sustained attention. This includes a number of autobiographical works by Rwandan refugees who survived the ordeal of their forced exodus to the DRC in 1996-7, and which together offer a rich lode of information on this gruesome episode. ${ }^{4}$ All too rarely are they mentioned in the literature on the DRC, a shortcoming from which I claim no exoneration. Nor have I given the visibility they deserve to the wealth of early materials-many identified with what Benoit Verhaegen aptly called l'histoire immédiate-published by the Brussels-based Centre de Documentation sur l'Afrique, and the valuable Dossiers du CRISP, published jointly by the Centre de Recherche et d'Information Socio-Politiques and the Institut d'Etudes Politiques in Kinshasa..$^{5}$ Though somewhat dated, they are not to be dismissed, as shown by Emizet Kisangani's eclectic use of such materials in his wideangled analysis of the Congo civil wars. Since then a new generation of highly talented scholars has emerged, ready to challenge accepted ideas and strike out in new directions. In trying to rethink some of my own views on the tortured history of eastern DRC, I have drawn much of my inspiration from their pioneering works. I owe them a lot more than can be properly expressed in a footnote. ${ }^{6}$

\section{JOURNEYS TO THE BORDERLANDS}

As a point of entry, a word or two about the shock I experienced after returning to the shores of Lake Kivu in 1993-33 years after my first visit-and then again in 2008 and 2009. Like many visitors before me, I still remember my sense of wonder upon discovering for the first time the magical landscape unfolding before my eyes. Alexander Barns rhapsodized about it in the I920s, and so did Alan Moorehead in the I950s, in words that still rang true when, as a young doctoral student, I became the guest of the magnificent (and now long defunct) Institut pour la Recherche Scientifique en Afrique Centrale

World War: Congo, the Rwandan Genocide, and the Making of a Continental Catastrophe (Oxford, 2009); S. Autesserre, The Trouble with the Congo: Local Violence and the Failure of International Peacebuilding (Cambridge, 2010); J. Stearns, Dancing in the Glory of Monsters: The Collapse of the Congo and the Great War of Africa (New York, 20II); E. F. Kisangani, Civil Wars in the Democratic Republic of Congo, I960-20Io (Boulder, CO, 20I2); D. Van Reybrouck, Congo: une histoire, trans. I. Rosselin (Arles, 20I2). Finally, no attempt to deal with the historiography of the Great Lakes would be complete without mentioning L'Afrique des Grands Lacs, a yearbook published since I997 under the auspices of the Antwerp-based, Centre d'Etude de la Région des Grands Lacs d'Afrique, an indispensable source of continuing information and ongoing research.

4 I have in mind, in particular, J. Karimumuryango, Les réfugiés rwandais dans la région de Bukavu, Congo RDC: la survie du réfugié dans les camps de secours d'urgence (Paris, 2000); M. Niwese, Le peuple rwandais un pied dans la tombe: récit d'un réfugié étudiant (Paris, 200I); and M. B. Umutesi, Surviving the Slaughter: The Ordeal of a Rwandan Refugee in Zaire (Madison, WI, 2004).

5 B. Verhaegen, 'The method of 'histoire immédiate': its application to Africa', in B. Jewsiewicki and D. S. Newbury (eds.), African Historiographies: What History for Which Africa? (Beverly Hills, CA, I986), $236-248$.

6 I have in mind, in addition to Autesserre's brilliantly iconoclastic prize-winning book, The Trouble with the Congo, the contributors to a special issue of the Review of African Political Economy (ROAPE), a treasure-trove of outstanding research papers: M. Larmer, A. Laudati, and J. F. Clark (eds.), special issue "Neither war nor peace in the Democratic Republic of Congo (DRC): profiting and coping amid violence and disorder," ROAPE 40:135 (2013). 
(IRSAC) in Lwiro, near Bukavu, in September 1960..$^{7}$ The ravages that have since swept across the region - only partially visible in the overcrowded urban landscape and collapsing infrastructures - have transformed this once idyllic playground into something of a dystopia. The impact of civil strife on the environment is evocative of a tsunami obliterating the shoreline, transforming Bukavu and Goma-capitals, respectively, of the provinces of North and South Kivu - into vast slums sheltering the human detritus generated by chronic rural violence.

Barely altering the bleakness of this picture are the few patches of relative calm and luxury surrounding the presence of humanitarian NGOs. Human and environmental disasters attract NGOs like filings in a magnetic field, and the latter in turn drastically reshape the contours of the social landscape. What is coming into view in Goma and Bukavu is a landscape dominated by 'NGOpoles', where the comfortable headquarters of hundreds of NGOs coexist, cheek by jowl, with peripheral slums bursting at the seams with ceaseless flows of internally displaced peoples (IDPs). ${ }^{8}$ The result has been to sow the seeds of further tensions. Speaking of the prospect for 'additional conflicts and contrasts', Karen Büscher and Koen Vlassenroot note how the concentration of humanitarian NGOs has tended 'not only to reinforce the discrepancy between centre and periphery, but also confirmed the spatial divide between urban rich and poor', a state of affairs, they aptly notice, 'mostly disregarded in academic humanitarian studies'. 9 The consequences go far beyond the urban perimeters: among the youth living on the fringes of the 'NGOpoles' many have no other option, in the face of prolonged unemployment, than to return to the bush. ${ }^{\text {IO }}$

Despite dramatic changes in the physical and social landscape, eastern Congo remains, pre-eminently, a 'borderland area'. The term has become increasingly fashionable among historians as a shorthand device to describe the dynamics of population movements, contested territorial claims, and shifting identities that are likely to be found wherever geographical boundaries are drawn across linguistic or cultural aggregates. What defines a borderland is nowhere more aptly captured than in the following commentary from two eminent historians of Eastern Europe:

Borderlands are places of interaction. They are regions intersected by frontiers that separate states .... But [they] are frontiers in another sense as well. They are spaces-in-between, where identities are often malleable and control of the territory and the population is subject to dispute.... Borderlands are therefore also constructs of the political imaginary and products of ideological

7 'A lovely pool of green water, set among some of the most splendid forests and mountains of all Africa', is how Moorehead captured the lushness of the Kivu region; Barns for his part found Kisenji (sic) to be 'in some ways the most beautiful and restful place I know, with just a touch about it reminiscent of the South Seas'. A. Moorehead, No Room in the Ark (London, I962 [orig. pub. I957]), 70; T. A. Barns, The Wonderland of the Eastern Congo: The Region of the Snow-Crowned Volcanoes, the Pygmies, the Giant Gorilla, and the Okapi (New York, 1922), 55.

8 This is the term used by K. Büscher and K. Vlasseroot in their discussion of 'The humanitarian industry and urban change in Goma', Open Democracy, 2I Mar. 20I3, (http://www.opendemocracy.net).

9 Ibid.

Io For a fuller exploration of this theme, see T. Raeymaekers, Forced Displacement and Youth Employment in the Aftermath of the Congo War: From Making a Living to Making a Life, MICROCON Research Working Paper, no. 38, (Brighton, 20II). 
fantasies .... In the borderlands, diverse populations may coexist for long stretches of time, only to have the harmony ruptured by episodes of violence .... [G]roups become both objects and generators of intense violence. ${ }^{\text {II }}$

Here, then, are some of the contextual elements behind inter-group violence in eastern DRC: a factitious frontier separating one group of Kinyarwanda-speakers from another (a pattern typical of several other groups); a frontier whose legitimacy is being contested on the basis of its presumed precolonial configuration; a frontier that sets the rights of the first occupants (Congolese) against the claims of immigrants, whilst giving free rein to ideological fantasies. Though living side by side in relative harmony for centuries, these populations have come to see each other, in the words of Lars-Christopher Heuning, as 'essentially different and naturally hostile', thus becoming 'both objects and generators of intense violence'. This phrase captures in a nutshell the essence of the dilemma facing the Banyarwanda minority of eastern Congo. ${ }^{\mathrm{I} 2}$

The relevance of the 'borderland' concept emerges with compelling clarity from David Newbury's outstanding collection of essays on the precolonial history of the Great Lakes region, The Land Beyond the Mists. ${ }^{{ }^{13}}$ As the following excerpt suggests, there are important lessons for historians of the present to learn from his unblinking gaze at the distant past. His purpose, he writes, is to place in historical context the protean character of the institutions and mental constructs that observers often assume to be fixed and permanent':

We will explore the nature of frontiers, ${ }^{\mathrm{I} 4}$ not boundaries; of personal experiences, not state histories; of multiple agency, not defining centers of historical legitimacy; and of local initiatives, not only central policies. While state power was important in this area, most people, most of the time, were not preoccupied with court politics or with state norms; their lives were lived outside of those familiar institutions that outsiders rely on to structure their knowledge. To understand their lives, therefore, we, too, need to venture beyond the conventional lines of inquiry to ask different questions, and to adopt different perspectives on conventional topics. ${ }^{15}$

In a similar vein, and in line with some of the recurrent themes in the recent literature on DRC, a persuasive case can be made for focusing less on the state and more on local institutions and initiatives. It is at this level, where informal social nets serve as alternatives to the state, that Newbury's research brings out some significant continuities between the pre and postcolonial eras.

I I O. Bartov and E. D. Weitz, 'Introduction', in Bartov and Weitz (eds.), Shatterzone of Empire: Coexistence and Violence in the German, Habsburg, Russian, and Ottoman Borderlands (Bloomington, IN, 20I3), I.

I 2 The term Banyarwanda includes Hutu and Tutsi; both speak Kinyarwanda, and trace their origins to Rwanda. But this does not take into account the date and circumstances of their migration into eastern DRC, which, along with their places of residence, point to further distinctions among them. See Lars-Christopher Huening's excellent analysis, 'Making use of the past: the Rwandophone question and the "Balkanisation of the Congo"', ROAPE, 40:135 (2013), I3-3I.

I3 D. S. Newbury, The Land Beyond the Mists: Essays on Identity and Authority in Precolonial Congo and Rwanda (Athens, OH, 2009).

I4 Here defined as 'an area of poorly defined contours and quickly changing perceptions', Ibid. 6.

I Ibid. 3-4. 


\section{DEFINING MOMENTS}

Since its independence in I960, the Congo has oscillated between moments of fragile stability, associated with Mobutu's Bula Matari rulership, and chronic outbreaks of coups, mutinies, rebellions, armed invasions, and secessions. ${ }^{16}$ There is no precedent, however, for the nightmarish upheavals that followed in the wake of the Rwanda genocide in I994. Whether measured in terms of human losses, displacement of civilian populations, destruction and theft of property, sexual abuse and humanitarian emergencies, the first and second Congo wars (1996-7, 1998-2003) stand out as exceptionally brutal phenomena. Their complexity defies attempts at reducing them to any single set of factors, whether described as resource wars, sexual abuse, greed, ethnic hatreds, or neo-imperial spheres of influence. More than anything else, it is the sheer scale of human loss that defines their singularity.

According to the best estimates, civil strife in DRC translates into the loss of approximately 3.3 million lives between August 1998 and November 2002. ${ }^{17}$ Battlefield casualties only account for a small fraction of such deaths; the vast majority are attributed to malnutrition, disease, and sheer exhaustion. The multiple shards of social dislocation, illness, hunger, rape, and displacement are among the most lethal of the legacies inherited from the Congo wars. Others, no less dangerous in their implications, involve basic disagreements over 'what really happened' and what to do about it.

The forced migration of millions of homeless people, generally lumped together under the aseptic acronym of IDPs, speaks volumes for the scale of the violence that has engulfed the region. ${ }^{\mathrm{I} 8}$ While there is broad consensus among observers about the significance of the watershed event-the massive outpouring of I.2 million Rwandan Hutu across the border into DRC - not everyone agrees about the motives, scale, and moral implications of the subsequent Rwandan intervention. Gérard Prunier leaves few doubts in the reader's mind about the atrocities committed by the Rwandan army in the name of the security imperative. Nor does Filip Reyntjens downplay this theme. ${ }^{\text {I9 }}$ Their take on these events, whilst consistent with the 20I0 United Nations (UN) Mapping Report, is in sharp contrast, however, with the interpretations offered by other observers, whose

I6 On the Bula Matari concept to denote an oppressively strong state syndrome, see C. Young, The African Colonial State in Comparative Perspective (New Haven, CT, I994), 77-I40.

I7 Human Security Report 2005: War and Peace in the $2 I^{\text {st }}$ Century, pub. for the Human Security Center of the University of British Columbia (Oxford, 2005), I34.

I 8 Recent statistics from the UN Office for the Coordination of Humanitarian Affairs (OCHA) indicate that in 2012 alone, fighting in North Kivu displaced some 590,000 people. By 20I3, according to Refugees International (RI) the number of IDPs for the province had reached nearly a million (9I4,000); of these 802,000 were reported to be living outside the formal camp settings. According to RI advocate Caelin Briggs, 'Across the board, we found extremely harsh conditions, particularly in the non-official camps .... Food is the number one need mentioned. For instance, between July and December 20I 2, there was no food distribution in Masisi [territory]. They try to get day labour on nearby farms, but there is just not enough work to go around.' 'Boosting support for IDPs outside DRC's formal camps', International Research Information Network (IRIN), (Nairobi), 2I Mar. 20I3, (http://www.irinnews.org).

I9 Prunier, Africa's World War; Reyntjens, The Great African War, passim. 
angle of vision is largely focused on the need to eliminate the Hutu génocidaires, not the moral obligation of saving civilian lives (more of which later). ${ }^{20}$

For all its devastating human and political costs, the IDP phenomenon has received surprisingly little systematic attention from students of international humanitarian law. One of the few to address the issue is Jennifer Leaning, who makes a strong plea for the International Criminal Court to include on its agenda a category 'in which to document these harmful effects and prosecute those responsible for causing them to occur'. She explains:

The dynamics of these current internal wars rely on forcing large civilian populations to flee their homes and their land and making it impossible or highly unlikely that they can return.... This strategy and resulting tactics arise from the characteristics of the non-state actors who conduct these wars.... Their intent is to kill or chase away populations, overtake their land, plunder their wealth, and extract resources over the long-term.... In the DRC, scores of people in one village attack might be raped and/or killed, and the survivors of that village and people nearby would run far into the forest to seek refuge in villages farther away-only to be forced to flee again when armed groups moved in that direction. ${ }^{2 \mathrm{I}}$

There is more to this grim scenario than a litany of human dramas unfolding in far away places, with names like Bwito, Rutshuru, Shabunda, or Walikale. It goes to the heart of the mechanism that makes violence a self-perpetuating phenomenon. As I have argued elsewhere, drawing on the insights of Myron Weiner, massive population movements, whether in the form of IDP or refugee flows, must be seen as major vectors of conflict within as well as between states. The pattern is depressingly the same throughout the region, that is, one in which a succession of crises, each feeding on the other, sets in motion a deadly and seemingly unstoppable engrenage-oppression leading to insurrection, insurrection to repression, repression to mass migration of refugee populations to neighboring states where they generate further conflict, and eventually pave the ground for intervention. ${ }^{22}$ This is nowhere more dramatically illustrated than in the Great Lakes borderland, where the role of Rwanda has had a profoundly polarizing effect far beyond its boundaries.

\section{RWANDA: VILLAIN OR SAVIOR?}

In the minds of many Western observers, the image of Rwanda is inseparable from President Paul Kagame's presumptive claims to fame, his determination to stop the bloodshed, his impressive military skills, and unsurpassed talent for making an economic

20 United Nations Office of the High Commissioner for Human Rights, Report of the Mapping Exercise documenting the most serious violations of human rights and international humanitarian law committed within the territory of the Democratic Republic of the Congo between March I993 and June 2003 (Geneva, 20I0). For an excellent short analysis, see J. Stearns, 'Bombshell UN Report leaked: "Crimes of genocide” against Hutus in Congo' guest blogger to the Christian Science Monitor online, 26 Aug. 2010, (http://www.csmonitor.com).

2 I J. Leaning, 'Enforced displacement of civilian populations in war: a potential new element in crimes against humanity', International Criminal Law Review, I I:3 (20I I), 446.

22 Lemarchand, The Dynamics of Violence, 20; see also M. Weiner, The Global Migration Crisis: Challenge to States and to Human Rights (New York, I995). 
miracle happen. His ability to manipulate the media also helped, as did the abysmal ignorance of the most elementary facts of Rwandan history displayed by some of his most ardent supporters in the United States and the United Kingdom. The central fact that tends to eclipse all others is, of course, the appalling genocide perpetrated against innocent Tutsi civilians and moderate Hutu during the hundred days following the crash of former President Habyarimana's plane on 6 April I994. Far too little attention, on the other hand, has been paid to the wholesale extermination of Hutu civilians by the Rwandan military within and outside Rwanda in the months following the capture of power by Kagame on 4 July I994. It is much to the credit of the new historiography to turn the spotlight on such long-forgotten acts of genocide. ${ }^{23}$

This is not the only contribution of this new group of historians. Tempting as it is to view Rwanda as the central villain in a regional power play, villainy, they note, was widely shared. Harbingers of conflict were present in DRC long before the Rwandan invasion. In his wide-ranging analysis of the pre-I996 dynamics of internal conflict, Koen Vlassenroot shows how the legacy of former President Joseph Mobutu's patrimonial networks, the land question, and the nationalist issue all contributed to set the stage for future confrontations. ${ }^{24}$ Thomas Turner goes even further back in time, turning his attention to the I959 Hutu revolution in Rwanda, the threshold event that forced tens of thousands of Tutsi refugees to seek refuge in the Congo, Burundi, and Uganda. ${ }^{25}$ A great deal more, however, could have been said of what I would not hesitate to describe as a critical turning point in the history of the DRC.

In his thoughtful discussion of 'the myth of the closure of history' - one of the four myths affecting the 'recent historiography of Central Africa' - Newbury laments 'the tendency to "stop" history at a given point ... and substitute a "moment" for a long complex process, worked out at many levels.. ${ }^{26}$ The impulse to 'stop the clock' helps explain the all too casual attention paid to the calamitous regional fallout of the 1959 Hutu revolution in Rwanda. Few episodes in the history of the DRC offer a more dramatic illustration of the Burkean law of unintended consequences: what had not been anticipated was the lasting impact on neighboring states of the exodus of an estimated 80,000 Tutsi refugees - of whom anywhere from 40,000 to 50,000 found asylum in the Kivu province. ${ }^{27}$ In Burundi, the influx of Tutsi exiles played a determining role in polarizing Hutu-Tutsi relations. In Uganda, they nurtured the refugee warriors who fought their way back into Rwanda in October 1990. In the Congo, they were able to bring about a radical shift in Mobutu's

23 Reyntjens, The Great African War, esp. 80; Reytnjens and Lemarchand, 'Mass Murder in Eastern Congo, 1996-1997', in Lemarchand (ed.), Forgotten Genocides: Oblivion, Denial and Memory (Philadelphia, $20 \mathrm{II}), 20-36$.

24 K. Vlassenroot, 'Reading the Congolese crisis' and 'Land and conflict: the case of Masisi', in K. Vlassenroot and T. Raeymaekers, Conflict and Social Transformation in Eastern DR Congo (Gent, 2004), 39-60 and 8I-IO2; K. Vlassenroot, 'The promise of ethnic conflict: militarisation and enclave formation in South Kivu', in D. Goyvaerts (ed.), Conflict and Ethnicity in Central Africa (Tokyo, 2000), 59-104.

25 Turner, The Congo Wars, II4.

26 D. Newbury, 'Canonical conventions in Rwanda: four myths of recent historiography in Central Africa', History in Africa, 39: (2012), 54.

27 C. Braeckman, 'Zaïre et ses régions', Enjeux Nationaux et Dynamiques Régionales dans l'Afrique des Grands Lacs: interventions et communications de la journée d'étude (Lille, I992), 33-4I. 
policies on land and nationality, thanks to the meteoric rise to power of a fiendishly astute Tutsi exile, Bisengimana Rwema, who by 1972 held the title of chief of staff (chef de cabinet) in the presidential office.

Unlike previous generations of migrants to eastern DRC the so-called 'fifty-niners' were overwhelmingly Tutsi; they were drawn for the most part from the upper stratum of the Tutsi community; they were relatively well-educated, and claimed administrative skills and resources unmatched by their predecessors. Some of the newcomers were able to accumulate considerable wealth through land deals and agro-business enterprises. The figure cited by Prunier gives us a sense of the enormity of the land grabbing that went on at the time: it reached 'such incredible proportions', he writes, 'that in I980 the Land Ministry in Kinshasa had to cancel the attribution of 230,000 hectares $(575,000$ acres) to the notorious Rwandan businessman Cyprien Rwakabuka'. ${ }^{28}$ The result has been to squeeze a large number of Congolese peasants out of their traditional holdings and sow the seeds of ethnic hatred. The violent outburst of anti-Rwandan feelings in I993 demonstrated the full measure of the impact of land alienation on indigenous communities, mainly Hunde, Nyanga, and Tembo. ${ }^{29}$ This murderous episode serves as an object lesson for many of the land issues in eastern DRC. Above and beyond the confusion between statutory and customary rights, the most vexing aspects of the land problem center on the irreconcilable claims of those communities who, by the force of circumstance, became successive occupants of the same plot, one displacing the other, more often than not by violent means.

Neglecting the heritage of the past is not the only problem. In fixating on Kagame's continuing potential for nuisance, it is all too easy to downplay the threats posed by proxy movements from other neighboring states, notably Angola and Uganda. Reyntjens is one of the few scholars, along with Miles Larmer, to have paid due attention to the military intervention of the Angola-based (and now largely forgotten) Katanga Gendarmes (aka les Tigres) during the anti-Mobutist crusade led by the Alliance des Forces Démocratiques pour la Libération du Congo-Zaire (AFDL). ${ }^{3 \circ}$ Kristof Titeca and Koen Vlasssenroot for their part have described the complicated itinerary of the Uganda-based Allied Democratic Forces (ADF), which, in their terms, is operating from Congolese soil but so far has attracted very limited scholarly attention'. ${ }^{\text {I }}$ Hardly better known is the pivotal role played by Burundi during the so-called Simba rebellion of I 964-5: how, through their ties with the pro-Chinese radical Tutsi ministers in Bujumbura, the Cuban-backed Congolese rebels headed by Laurent Kabila were able to funnel arms and ammunition to eastern Congo stands as a major episode of this now largely forgotten

28 Prunier, Africa's World War, 49. The author, however, offers no evidence in support of this astronomical figure.

29 F. Reyntjens and S. Marysse (eds.), Conflits au Kivu: Antécédents et Enjeux, (Antwerp, I996); Human Rights Watch, Zaire: Forced to Flee-Violence Against the Tutsis in Zaire, 8:2 (July I996).

30 Reyntjens, The Great African War, 6I-3; M. Larmer, 'Local conflicts in a transnational war: the Katangese gendarmes and the Shaba Wars of I977-78', Cold War History, I3:I (2013), 89-Io8. I am grateful to Miles Larmer for drawing my attention to both Reyntjens's and his own contributions.

3 I K. Titeca and K. Vlassenroot, 'Rebels without borders in the Rwenzori borderland? A biography of the Allied Democratic Forces', Journal of Eastern African Studies, 6:I (20I2), I 54. 
drama. The general theme of 'rebel movements and proxy warfare', to borrow the author's title, is at the heart of Prunier's illuminating discussion of the flurry of proxy guerilla organizations that have contributed to the Congo's disasters. ${ }^{32}$ The Congo's continuing vulnerability to the penetration of external actors helps explain the extreme fluidity of the alliances that have come into play among proxy groups and their parent organizations - a theme masterfully analyzed by Reyntjens in his early work on the Great Lakes. ${ }^{33}$

A dispassionate assessment of the consequences of Rwandan intervention is not made any easier by the radically different interpretations offered by pro- and anti-Kagame analysts. ${ }^{34}$ Where some applaud his moral determination in eradicating the génocidaires, others condemn his participation in acts of genocide against Hutu civilians; where some vehemently deny his support of rebel militias in DRC, others denounce his double-dealing; where some insist that the Congolese government bears full responsibility for the DRC's problems, others point an accusing finger at Kagame.

An egregious example of how personal prejudice and teleological biases are likely to distort reality is Howard Adelman's discussion of 'The Use and Abuse of Refugees in Zaire', a rare but thoroughly misguided effort to deal systematically with the refugee issue. While paying due attention to the security threats posed to Rwanda by the political extremists in their midst, the author, a professor of philosophy retooled into a Kagame advocate, has little to say about the genocidal search-and-destroy operations conducted by Kagame's army against Hutu civilians, with auxiliary support from the Rwanda-backed AFDL. The refugees, we are told, were 'liberated' (sic) by the AFDL, thus making possible the 'spontaneous repatriation' of 640,000 of them, a figure for which there is not a shred of reliable evidence. The conclusion, straight from the Kagame gospel, is that 'no significant number of missing genuine refugees existed when the camps were evacuated', meaning that the only Hutu left behind were elements of the ex-Forces Armées Rwandaises (FAR) and interahamwe. And yet reports from international NGOs became 'hysterical' in the face of what they 'proclaimed a humanitarian crisis'. ${ }^{35}$ Note the use of language: the refugee camps were 'evacuated', not brutally destroyed at a horrendous cost in human lives; the assault on the camps translates into a 'liberation'; expressions of concern by international NGOs were 'hysterical'. Murray Edelman's wry

32 G. Prunier, 'Rebel movements and proxy warfare: Uganda, Sudan and the Congo (I986-99)', African Affairs, I03:4I 2 (2004), 359-83.

33 F. Reytnjens, La Guerre des Grands Lacs: Alliances Mouvantes et Conflits Extraterritoriaux en Afrique Centrale (Paris, I999).

34 Among Kagame's corporate praise singers, the Howard Buffett Foundation deserves special notice for its blistering and largely gratuitous criticisms of the $20 \mathrm{I} 2 \mathrm{UN}$ Group of Experts on the DRC, listed in this commissioned report: Assessing the 2012 UN Group of Experts Report on the DRC: An Analysis of Methodology, Cooperation and Implications (I Apr. 2013). For a more persuasive argument, see T. Turner, 'Will Rwanda end its meddling in Congo?', Current History, I I 2:754 (2013), I88-94.

35 H. Adelman, 'The use and abuse of refugees in Zaire', in S. J. Stedman and F. Tanner (eds.), Refugee Manipulation: War, Politics, and the Abuse of Human Suffering (Washington, DC, 2003), 95-I34, quotes from pages 99, I00, and I20. For a similarly tendentious interpretation of Rwanda's role in DRC, see H. Adelman and G.C. Rao (eds.), War and Peace in Zaire/Congo: Analyzing and Evaluating Intervention, I996-I997 (New York, 2004). 
commentary comes to mind: 'Language is the key creator of the social worlds people experience, not a tool for describing an objective reality. ${ }^{36}$

\section{RANDOMNESS AND PATH-DEPENDENCE}

Diagnoses of the Congo crisis usually center on two opposing sets of assumptions, neither of which carries the assurance of a cure. One focuses on Rwanda as the perennial spoiler; the other draws attention to a range of problems inherent in the DRC, including the inability of its leaders to lay the foundation of a functioning state. Although the dichotomy is somewhat reductive, it nevertheless points to different ways of meeting the challenge of reconstruction, and ultimately of looking at the history of eastern DRC.

Seen through the prism of Congo's recent historiography a significant distinction emerges between contingency and dependency as the prime movers of the crisis. In one case, randomness and unpredictability are the hallmarks of history; in the other, path-dependence is the analytic frame that enables us to make historical sense of what happened. In its broadest sense it means, in the words of Kathleen Thelen, that 'what has happened at an earlier point in time will affect the possible outcomes of a sequence of events occurring at a later point in time'. ${ }^{37}$ It is easy to see why the first of these approaches often tends to eclipse the other. Who could have imagined in the wake of the Belgian-engineered I959 Hutu revolution that it would sow the seeds of the 1994 genocide $?^{38}$ Who would have thought that the offspring of the Tutsi monarchists forced out of their homeland by a Belgian-supported insurrection would re-enter Rwanda as selfproclaimed 'liberators', some 35 years later? Who could have predicted that the massive exodus of Hutu génocidaires into the Congo would eventually serve as the pretext for a Rwanda-engineered genocidal slaughter of Hutu civilians? Who could have foreseen the dramatic reshuffling of alliances following former President Laurent Kabila's break with his Rwandan patrons, causing the Hutu rebels to join hands with the newly enthroned Congolese leader, the same Kabila who only a few months earlier looked the other way whilst hundreds of thousands Hutu civilians were being massacred by the Rwandan army?

Nonetheless, closer scrutiny of the evidence suggests important ways in which 'history matters'. The preceding section offers at least one major example (the I959 Hutu revolution), to which might be added the consistency with which over a period of years Rwanda has manipulated one set of Congolese rebels after another, or for that matter the causal links between the 'critical juncture' represented by the I 994 genocide and subsequent retributive moves within and outside Rwanda. But there is another sense in which the past intrudes into the present, as a constructivist fantasy aimed at casting discredit on the Tutsi community as a whole: in the minds of many self-styled autochtones their history

36 M. Edelman, Constructing the Political Spectacle (Chicago, I988), I03.

37 K. Thelen, 'How institutions evolve: insights from comparative historical analysis', in J. Mahoney and D. Rueschemeyer (eds.), Comparative Historical Analysis in the Social Sciences (Cambridge, 2003), 2 I 8 .

38 The crucial role played by the Résident Spécial, Colonel Guy Logiest, in orchestrating the Hutu revolt, and institutionalizing the transfer of power to Hutu elites, is made clear in his autobiographical account, Mission au Rwanda: Un Blanc dans la Bagarre Tutsi-Hutu (Paris, I988). 
points not just to their foreign origins but, more ominously, their hidden imperial designs as a fifth column serving Kigali's interests. ${ }^{39}$

Even where analysts agree on the contingent nature of events leading to the wars, there is still room for dissent as to what factors really mattered, where, and when. Whether framed in terms of international discords, state decay, refugee flows, or external intervention, or a combination thereof, these are only some of the explanatory variables vying for recognition. A fuller listing can be found in Turner's wide-ranging meditation on 'classifying and explaining the Congo wars'.$^{\circ}$ Though some facts are irrefutable, their consequences are by no means self-evident. Yet the impulse to 'let the facts speak for themselves' is hard to resist. E. H. Carr's admonition is worth remembering: 'the facts speak only when the historian calls on them: it is he who decides to which facts to give the floor and in what order'. Borrowing a metaphor from one of Pirandello's characters, he adds: 'a fact is like a sack - it won't stand up till you've put something in it'. ${ }^{\text {I }}$ In more prosaic language, what matters is how facts are selected, weighted, and interpreted.

But if the facts rarely speak for themselves, the words spoken by political actors are worth registering. Witness the engrossing narratives offered by David Van Reybrouck and Jason Stearns: the venomous quality of Congo politics comes across with dramatic force through the voice of their interviewees. This is particularly true of Van Reybrouck's riveting account, hailed by one Dutch newspaper as 'the book of the year'. ${ }^{42}$ Nothing is more cruelly illustrative of the horrors of the Congo wars than the wrenching stories recorded verbatim from child soldiers. In the last few chapters of the book, dealing specifically with eastern DRC, the author grapples with many of the same themes explored elsewhere by other analysts, but refracted through the lived experiences of key protagonists. Among them are adventurers, fly-by-night operators, poachers, musicians, soccer stars, most of them adept at multi-tasking; but few are as outspoken and revealing of the unpredictability of history as Ruffin Luliba, the child soldier who after being press-ganged into joining the AFDL ended up as a bodyguard for Kagame's chief of staff (James Kabarege) before serving in the same capacity for Kabila père. Among many other telling vignettes there is the story of the anonymous child soldier who, aged I2, joined the Rwanda-backed Hema-dominated Union des Populations Congolaises (UPC), and for the next three years won his spurs under the guidance of Rwandan mercenaries, led by none other than Bosco Ntaganda (now awaiting the verdict of the International Criminal Court): 'We were trained by Rwandan mercenaries. Our general was Bosco Ntaganda. He also fought with Joseph Kony. We captured mothers, fathers and children. We were told to kill and I killed. Killing women and children I didn't like. Fortunately I had a gun. I was afraid to use a machete. Soldiers took away the girls to

39 The term is borrowed from Crawford Young's seminal analysis of the three major variants of ethnicity, primordial, instrumentalist, and constructivist, in The Postcolonial State in Africa: Fifty Years of Independence, I960-2010 (Madison, WI, 20I2), esp. 3 I 8.

40 Turner, The Congo Wars, 8-Io.

4 I E. H. Carr, What is History? (London, I990 [orig. pub. I96I]), II.

42 Van Reybrouck, Congo: une histoire. 
marry them. Bosco used to say "When you join the army you get a wife for free. Everything is gratis". 43

In his Dancing in the Glory of Monsters, a brilliant mix of anecdote and analysis, Jason Stearns is similarly unflinching when confronted with the unspeakable. His interviews with professional killers are difficult to forget: 'Papy could kill up to a hundred of these dissidents-sometimes old women and young children-a day, usually using a rope to crush their windpipes and strangle them'. ${ }^{44}$ What these books have in common is a recognition of the importance of individual testimonies, personal accounts, even body language, in any attempt to reconstruct the past. While providing fresh perspectives on historical events, they are also the best way to save them from oblivion.

History, clearly, is not without a logic of its own. This is made reasonably clear in the works of Prunier, Reyntjens, Turner, and Kisangani, all of them specifically concerned with sketching out the historic paths and turning points of the Congo crisis. Prunier's heavy tome, Africa's World War, offers a wealth of interesting insights into the regional chessboard over which domestic and international actors calculated their strategic and tactical moves. Reyntjens has few rivals when it comes to combining historical depth with a keen awareness of the regional context. This is also true of Turner's Congo Wars, which takes us on a fascinating exploration of issues of ethnicity in North and South Kivu, seen in a time-space perspective. Kisangani's Civil Wars in the DRC, I960-20Io is even more ambitious in the scope and depth of his analytic lens, showing how the historical context of Congo's internal wars, beginning with the Kwilu and Simba rebellions, throws into sharp relief the continuing impact of exclusion as the root cause of violence.

What all of the above share is a sense of historical depth as a corrective to structural explanations. No wonder if the once fashionable Collier-Hoeffler $(\mathrm{CH})$ model-which sets forth the argument that political and social grievances are of secondary importance in explaining civil wars as compared to the opportunities available to rebels to organize and finance their insurgencies - has been repeatedly found wanting when applied to the DRC. What makes the model less than useful is its blissful disregard of basic historical facts. Tellingly, in a collaborative volume designed to test the $\mathrm{CH}$ model, the authors of the chapter on DRC convincingly demonstrate its weakness; to quote Leonce Ndikumana and Kisangani Emizet:

Even though the $\mathrm{CH}$ model correctly predicts a large increase in the risk of war in the r99os, it leaves out risk factors that according to our case study are critical to understand civil war in the DRC. The most important ones are the trigger factors, especially the influx of Rwandan Hutu refugees that disrupted the ethnic balance and exacerbated land disputes in eastern

43 The Hema, whose homeland is in the Ituri district, are ethnically distinct from the Tutsi or Hima people but share some of the same historical experiences as a privileged minority during the colonial era; through ethnic favoritism or skullduggery they were able to claim ownership of large tracts of land previously owned by the majority Iru populations. Quote is from Van Reybrouck, Congo: une histoire, 492-3.

44 Stearns, Dancing in the Glory of Monsters, IO. 
Congo, the military activity of Rwandan militias that induced Rwanda to take an aggressive stand, and the nationality laws that targeted Congolese of Rwandan origin. ${ }^{45}$

Which brings us to another distinction between works that are largely descriptive, focused on the history of the present, and those that are more concerned with policy analysis and prescription. Two books, in particular, are emblematic of such divergent approaches. One is Stearns's previously mentioned Dancing in the Glory of Monsters, a narrative that captures the potency of histories in the making; the other is Severine Autesserre's fine-grained analysis of the local roots of conflict. Informed by a solid grasp of the historical background, and a wealth of oral testimonies, the first offers a fascinating view of the murderous landscape of eastern DRC under the boot of the Rwandan army and its local allies. 'Jason Stearns is probably better qualified and better able than any man alive to write about the Congo', writes John Le Carré on the dust jacket. Though some may question the improbable source of the endorsement, there can be no doubt about his impressive command of l'histoire évènementielle, a fact amply confirmed by the excellence of the several monographs produced by the author under the auspices of the Rift Valley Institute. ${ }^{46}$

Radically different in style and inspiration is Autesserre's prize-winning book, The Trouble with the Congo, which comes as close to emulating the Hobsbawmian school of 'history from below' as any other work on the subject. Her concern is more to prescribe than to describe, to reform as much as to inform. In page after page of meticulous, empirically-grounded analysis she turns the spotlight on a range of local issues - chieftaincy and land disputes, contested grazing rights, factional oppositions, ethnic wrangles, etc. - all of which, she claims, are central to an understanding of the roots of conflict at higher levels. 'Local violence', she writes, 'was motivated not only by top-down causes, regional or national, but also by bottom-up tensions. Local agendas have held tremendous influence throughout modern Congolese history, and they have often been intertwined with macro-level dimensions.' ${ }^{7}$ Theoretically innovative, empirically grounded, her book stands as a major addition to the Congo literature. While cutting across many less well-known fine-grained articles and monographs on micro-politics - including the highly valuable collection of in-depth investigations of local rebel movements published under Rift Valley Institute's imprimatur-Autesserre's painstaking inquest has the additional merit of offering a range of bold policy recommendations. ${ }^{48}$

45 L. Ndikumana and K. F. Emizet, 'The economics of civil war: the case of the Democratic Republic of Congo', in P. Collier and N. Sambanis (eds.), Understanding Civil War: Evidence and Analysis, Volume I: Africa (Washington, DC, 2005), 82.

46 See J. Stearns, Raia Mutomboki: The Flawed Peace Process in the DRC and the Birth of an Armed Franchise (Nairobi, 20I3); PARECO: Land, Local Strongmen and the Roots of Militia Politics in North Kivu (Nairobi, 2013); North Kivu: The Background to Conflict in North Kivu Province of Eastern Congo (Nairobi, 2012); From CNDP to M23: The Evolution of an Armed Movement in Eastern Congo (Nairobi, 20I2). All of the above have appeared in print as part of the Rift Valley Institute's DRC-centered Usalama Project, of which Stearns is the Director.

47 Autesserre, The Trouble with the Congo, 38 , emphasis added.

48 Among other contributions on that theme, the following deserve special mention: K. Vlassenroot (ed.), Dealing with Land Issues and Conflict in Eastern Congo: Towards an Integrated and Participatory Approach (Conflict Research Group, Ghent, 20I2); Adeape, Arche d'Alliance, et RIO, Au-delà des 'Groupes Armés': Conflits locaux et connexions sous-regionales: L'exemple de Fizi et Uvira 


\section{GRASS-ROOTS DIMENSIONS}

Autesserre's argument raises some legitimate questions. Aside from the risks involved in conducting field investigations where large areas have been transformed into war zones, the sheer intractability of conflicts over land rights and chieftaincy positions should give us pause. A cursory glance at a meticulously researched monograph dealing with 'local conflicts and regional sub-connections' is enough to make us realize just how politically sensitive and deeply rooted are these issues. ${ }^{49}$ Consider the following two cases, reduced to their simplest expressions.

One of the more baffling aspects of the I964-5 eastern rebellion (also known as the Simba rebellion), which at one point engulfed almost half of the country, is the complex intermingling of local issues with the regional insurgency. The episode is not untypical of some of the situations observable in parts of eastern Congo. In his discussion of the dynamics of the insurrection, Crawford Young shows how a key rebel leader and former provincial minister, Adrien Omari, was able to secure a major foothold in the South Kivu region by 'linking the broader cause of the rebellion to a local chieftaincy dispute among the Fulero, a small but strategically situated ethnic group living in the Ruzizi plain, along the Burundi frontier, and in the surrounding mountains'. ${ }^{\circ}$ At the root of the discord lay competing claims to the chefferie des Barundi, inhabited by Barundi migrants established in the DRC long before the advent of colonial rule, traditional enemies of the Fulero. The dispute over who should rule the Barundi has yet to fade away. The simmering enmities between Barundi and Fulero came to a head again in 2000, when Floribert Ndabagoye, the son of a previous incumbent, turned to the Rwanda-backed Rassemblement Démocratique Congolais (RDC) for support against his archenemy, Philémon Kibinda, whom he described as 'an illiterate Fulero trying to usurp the mwamiship of the Barundi'. ${ }^{\text {I }}$ Just as in the I96os, when the Fulero's term of office came to an abrupt end after the collapse of the Simba rebellion, so did Ndabagoye's incumbency after the RDC withered away after losing the 2005 elections. His political career was brought to a tragic end by an assassin's bullet in 2012 .

Another example of the transformative impact of the RDC interregnum (I996-2005) refers to the long-standing efforts of the Banyamulenge-a group of ethnic Tutsi long

(Sud-Kivu, RDC) (Life and Peace Institute, Kalmar, Suède, 20I I); C. Huggins, Land, Power and Identity: Roots of Violent Conflict in Eastern DRC, (International Alert, London, Nov. 20Io); J.-C. Willame, Banyarwanda et Banyamulenge: Violences ethniques et gestion de l'identité au Kivu, Cahiers Africains, Collection Zaïre, années 90 (Paris, I997).

49 Au delà des 'Groupes Armés'.

50 M. C. Young, 'Rebellion and the Congo', in R. I. Rotberg and A. Mazrui (eds.), Protest and Power in Black Africa (Oxford, I970), 972.

5 I Interview with Floribert Ndabagoye, Bukavu, 20 Sept. 2008. Space limitations prevent a fuller discussion of how Kibinda allied himself with Mai-Mai warlords (Nakabaka and Zabuloni) against Ndabagoye, and how the latter in turn received the full support of the RCD governor of South Kivu, Leonce Chibalonza, to make good his claims to the mwamiship of the Barundi. For a more detailed account, see Au delà des 'Groupes Armés', 75-6. An outstanding in-depth discussion of the ongoing conflict surrounding the Barundi chieftaincy can be found in the International Crisis Group report, 'Comprendre les conflits dans l'Est du Congo (I): la plaine de la Ruzizi’, Rapport Afrique no. 206 (23 July 20I3), I-25. 
established in South $\mathrm{Kivu}^{52}$ - to claim a territory of their own in the Itombwe plateau, their traditional homeland. In addition to validating their claims to citizenship, they saw this strategy as the quickest way to confirm their land rights. ${ }^{53}$ The issue takes on particular significance if we recall that the status of the Banyamuylenge as citizens has been consistently contested by 'native' Congolese. Realizing that the redrawing of administrative boundaries would be at the expense of their customary jurisdiction, the Fulero and Babembe vehemently opposed the creation of what came to be known, albeit briefly, as the territoire de Minembwe. Only after relentless pressure from the pro-Tutsi RDC authorities on behalf of the Banyamulenge did the new entity come into existence. Their victory proved ephemeral, however. With the return to the status quo ante following the demise of the RDC in 2005, the Minembwe territory was promptly abolished. Despite or because of the annulment of the reform, the issue remains a source of bitter discords among local communities.

In sketching out the bare bones of these local disputes, my aim is not to challenge Autesserre's argument but to show its limitations: in addition to the enormous complexity of how land problems tie in with rebel movements, another challenge is the extreme diversity of issues and intervening variables covered by 'bottom-up agendas'. This is the sense of the conclusion reached by Joost Van Puijenbroek and An Ansoms from their investigation of land problems in Ituri: 'The great variety of land conflicts', they conclude, 'results from a unique and locally specific combination of governance aspects, demographic aspects, cultural aspects, historical aspects and local socio-economic interdependencies. ${ }^{54}$

Ethnicity is yet another complicating factor. It is not a matter of coincidence that ethnic issues lie at the heart of the case studies noted above. The extent to which the land problem cuts across issues of ethnicity is explored at length in a number of outstanding contributions, among which the pioneering works of Stanislas Bucyalimwe Mararo, Paul Mathieu and Jean-Claude Willame, Chris Huggins, and Vlassenroot deserve special recognition. ${ }^{55}$ While confirming the local roots of land issues, they also stressed the salience of ethnic ties as a key factor in sharpening tensions. This is still the case today. How to deal with the enduring hatreds born of sustained ethnic violence is a huge challenge. An appreciation of how present-day issues are filtered through memories of

52 Huening, 'Making use of the past', I3-3 I; K. Vlassenroot, 'Citizenship, identity formation and conflict in South Kivu: the case of the Banyamulenge', ROAPE, 29:93/4 (2002), 499-5 I6.

53 Here as elsewhere in DRC, access to landed property is contingent on proof of citizenship, a point stressed by Eric Kennes in his commentary on 'the fundamental importance of the Congolese nationality law: It determines access not only to political power but also to economic power through land rights.' E. Kennes, 'The Democratic Republic of the Congo: structures of greed, networks of need', in C. J. Arnson and I. W. Zartman (eds.), Rethinking the Economics of War (Washington, DC, 2005), I45.

54 J. Van Puijenbroek and A. Ansoms, 'A legacy from the past hindering the future: land conflicts in Ituri (DRC)', in A. Ansoms and S. Marysse (eds.), Natural Resources and Local Livelihoods in the Great Lakes Region of Africa: A Political Economy Perspective (New York, 20II), 49-67.

55 S. B. Mararo 'Land, power, and ethnic conflict in Masisi (Congo-Kinshasa), I940s-I994', The International Journal of African Historical Studies, 30:3 (I997), 503-38; P. Mathieu and J.-C. Willame, Conflits et Guerres au Kivu et dans la Région des Grands Lacs: Entre tensions locales et escalade régionale (Paris, I999); Vlassenroot, 'Land and conflict', $8 \mathrm{I}-\mathrm{IO} 2$; Huggins, Land, Power and Identity. 
the past is one of the merits of Turner's exemplary work - and this is also true of Prunier's. By drawing attention to the atrocities committed by Rwanda's client militia, RDC, they give us a measure of the mutual distrust, which to this day marks the gulf between 'them' and 'us'. Their chronicles echo Luc Heyse's lament on the wounds left by human rights violations, which persist 'comme une douleur fantôme dans le corps de ceux qui viennent à la suite....'

None of this detracts from the wisdom of Autesserre's policy recommendations. ${ }^{56}$ Whether or not one agrees with her brief, it seems unlikely that her counsels could be put into practice in the absence of a minimally functioning state system.

\section{NEW RESEARCH DIRECTIONS}

In line with Christopher Clapham's argument, a convincing case can be made for the view that peacebuilding is the fundamental precondition to statebuilding, not the other way around. ${ }^{57}$ This indeed is the raison d'être of the 3,000-strong intervention brigade sent out to the DRC under the auspices of the UN, with the mission to bring to heel the rebel faction $\mathrm{M}_{23}$. Whether the use of force is the best way to promote peace is where doubts arise: the dismal track record of both the UN Mission in the Congo (MONUC) and its successor, the UN Stabilization Mission to the Congo (MONUSCO), tells a cautionary tale.

It is significant that precisely as the UN intervention was beginning, I9 international NGOs sent a joint letter to the UN secretary general expressing concern over its mandate which, in addition to being more offensive than that of MONUSCO, ignores alternative ways of dealing with conflict, including 'local level dialogue to address the local issues of conflict and community grievances'. ${ }^{8}$ In other words, even where statelessness seems omnipresent, civil society organizations - whether through dialogue, service provision, or mediation - can conceivably provide 'structures of order' that can help manage local conflicts, and eventually act as institutional supports for what little is left of the state. 59

How can civil society create order out of near anarchy? How does it fit with state-centered arguments? These questions lie at the heart of the debate going on among scholars, consultants, and human rights activists about how best to lay the groundwork for stabilization in the DRC. At the risk of greatly oversimplifying the terms of the debate, two distinctive approaches can be identified: the more widely-publicized stresses the imperative of a state system capable of restoring a measure of stability; dissenters, on the other hand, point to the difficulty of creating a Weberian state in a Hobbesian environment. A more rational course of action, in such circumstances, is to turn to civil society for alternative solutions.

\footnotetext{
56 S. Autesserre, 'The trouble with Congo: how local disputes fuel regional conflict', Foreign Affairs, 87:3 (2008), I06.

57 C. Clapham, 'Peacebuilding without a state: the Somali experience', in D. Curtis and G. A. Dzinesa (eds.), Peacebuilding, Power, and Politics in Africa (Athens, OH, 2012), 295-309.

58 'NGOs concerned about new DRC Intervention Brigade', IRIN (Goma), 3 I May 20 I 3.

59 Clapham, 'Peacebuilding without a state', 302.
} 
Largely missing from the debate is a recognition of the extraordinary diversity of conflict situations encountered throughout eastern Congo. While the armed clashes between $\mathrm{M}_{2} 3$ and the Forces Armées de la Republique Democratique du Congo (FARDC) have attracted considerable attention, little is said of the far more numerous and potentially destabilizing conflicts over land resulting from the long-standing claims of Tutsi returnees, many of whom were forced out of their properties by the I994 flood of Hutu refugees and interahamwe. As tens of thousands of Tutsi refugees living in Rwanda are now looking for ways of recovering their lost properties, in anticipation of their return, the amount of future litigation will far exceed the rate of successful mediations. In the meantime, further complications have to be factored in: how conflicting claims are sometimes instrumentalized by local authorities is one of the many issues raised in a recent multi-authored paper on 'land grabbing by local elites', along with questions of ethnicity as they relate both to claimants and military mediators. ${ }^{60}$ Contextual variables are all-important. 'When the army changes, the problems also change' is how one Congolese summed up the fluidity of the parameters within which local conflicts evolve. ${ }^{6 \text { I }}$

Besides 'situating' conflicts in time and space, another challenge is to gauge the efficacy of civil society organizations in performing functions normally devolved upon the state, including conflict resolution. The case for taking a closer look at the responses of the civil society to state failure is brilliantly argued by Laura Seay and Ashley Leinweber in their recent analyses of the role of faith-based NGOs in providing community services, including health care and education. ${ }^{62}$ What makes their research particularly original is the attention paid to the state as an intervening variable. They both recognize that state weakness is not synonymous with statelessness, and that for all its deficiencies the state 'continually negotiates with non-state actors in the realm of social service provision, thus creating hybrid institutions that are run by a combination of state and non-sate actors'. ${ }^{63}$ Policy options need not be framed in terms of an 'either/or' choice between state and civil society. Nor is the only alternative between a Mobutist monster and a Weberian epiphany. Exactly how the hybrid offspring of state-society relations can help bring stability to the country is where speculations abound.

That there is no such thing as a neat demarcation between the state and civil society is well argued by Tom de Herdt in his recent work on state-building in DRC, in which the state is conceptualized as a 'processual phenomenon in which state and society must necessarily interact and negotiate the terms of their trade-offs, evolutions and dynamics' ${ }^{64}$ Others, pointing to the 'ambiguous state-NGO relations', stress the benefits drawn by civil

60 K. Claessens, E. M. Mudinga, and A. Ansom, 'Competition over soil and subsoil: land grabbing by local elites in eastern DRC', in A. Ansom and T. Hillhorst (eds.), Everyday Forms of Land Grabbing in the Great Lakes Region of Africa (forthcoming).

6I Ibid. IO.

62 L. E. Seay, 'Effective responses: Protestants, Catholics and the provision of health care in the post-war Kivus', ROAPE 40:I35 (20I3), 83-97; A. E. Leinweber, 'From devastation to mobilisation: the Muslim community's involvement in social welfare in post-conflict DRC', ROAPE 40:I35 (20I3), 98-II 5.

63 Leinweber, 'From devastation to mobilisation', I I I.

64 T. De Herdt, A la Recherche de l'Etat en R-D Congo: Acteurs et enjeux d'une reconstruction post-conflit (Paris, 2OII), 22-5. 
society organizations from the use of 'the state administration as a reservoir from which qualified personnel can be recruited or state infrastructure obtained'. ${ }^{65}$ The same blurring of boundaries between state and society comes across in Denis Tull's arresting discussion of structural continuities between the Mobutist polity and the 'rebel-ruled para-states': to speak of a collapse of the state, he suggests, makes little sense where the state is but the extension of a clientelist syndrome, and where patronage and patron-client ties have never ceased to operate at one level or another. ${ }^{66}$

Clientelism is emerging as a new theme in recent research on the DRC. The importance of patronage (for want of a better word) as a war resource is convincingly argued by Ann Laudati in her excellent discussion of 'the economies of violence', where resource extraction, including prebends and extortion, are a central feature of rebel politics. The same can be said of Judith Verweijen's intriguing characterization of the Congolese army, as an example of how militarized 'Big Man networks' shape the dynamics of state-society relations. ${ }^{67}$ In his anatomy of the social ties spawned by the Conseil National pour la Défense du Peuple (CNDP) and its successor movement, M23, Stearns is dealing with a specific variety of the same phenomenon. ${ }^{68}$

To conclude that clientelism is hard-wired into Congolese society is neither supported by evidence nor particularly illuminating. The more pertinent questions to ask are how patron-client ties come into being, where, in what form, and with what consequences for society. Clientelism is by nature protean and changing. It can bind and it can unbind; it can bring patrons and clients into networks that have more in common with mafia organizations than with political machines, and it can serve as legitimate channels for funneling resources into the hands of the needy; it can serve as a conduit for arms to rebel movements, and as a lifeline for NGOs to provide services to their clients.

A particularly neglected theme, I might add, is that of foreign-linked clientelism, perhaps the most enduring form of borderland dependency. Although Rwanda is of course the prototypical example of an external super-patron, other candidates, notably Uganda, have proved equally adept at using local connections for resource extraction on a massive scale. Though few would dispute the fact that the Congo's vast mineral wealth lies at the heart of such ties, just how far the illegal exploitation of resources accounts for interfactional violence is a matter of controversy. Some of Rwanda's closest allies in DRC - such as M23 - have enjoyed Kigali's military and logistical support irrespective of their involvement in the minerals trade, official denials notwithstanding. To this must be added that many other factors conspire to fuel violence, ranging from disputes over land,

65 M. Giovannoni, T. Trefon, J. K. Banga, and C. Mwema, 'Acting on behalf (and in spite) of the state: NGOs and civil society associations in Kinshasa', in T. Trefon (ed.), Reinventing Order in the Congo: How People Respond to State Failure in Kinshasa (London, 2004), 103.

66 D. M. Tull, 'A reconfiguration of political order? The state of the state in North Kivu (DR Congo)', African Affairs, 102:408 (2003), 429-446.

67 A. Laudati, 'Beyond minerals: broadening “economies of violence” in eastern Democratic Republic of Congo', ROAPE 4O:I35 (20I3), 32-50; J. Verweijen, 'Military business and the business of the military in the Kivus', ROAPE 40:135 (2013), 67-82.

68 J. Stearns, 'Repenser la crise au Kivu: mobilisation armée et logique du gouvernement de transition', Politique Africaine, I29 (Mar. 2013), 23-48. 
chieftaincy wrangles, and ethnic enmities. Behind the phrase 'conflict minerals' lies a range of phenomena far more complex than the phrase suggests. Sara Geenen, among others, draws attention to a 'whole web of social relations' that make up 'the mineral trade, including smuggling routes historically deeply rooted in local and regional dynamics'; she also notes that efforts at curbing the trade-such as the six-month ban on artisanal mining imposed by President Kabila in 2010-have been largely indifferent to the interests of the tens of thousands of individual miners whose livelihoods depend on continuing access to the artisanal mining sector. ${ }^{69}$ All of this lends considerable weight to Autesserre's contention that the conflict minerals argument, despite or because of its deceptively simple logic, 'has diverted attention from much needed policy actions, such as the resolution of grassroots antagonisms, the fight against corruption, and the reform of the state administration'. ${ }^{\circ}$ But if the DRC remains a textbook example of the resource curse-surrendering to armed groups revenue that otherwise could be generated by selling mining rights to foreign companies, it remains an open question whether a better fate can be expected for the country in the absence of a functioning state.

How patron-client ties can help us get a handle on the performance of civil society organizations is yet another area that cries out for more sustained attention. Clientelism can serve as a structure of escape from the constraints of the state, and as a means of capturing state resources. This is where analyses of civil society organizations raise interesting questions about their effectiveness as service providers distinct from the state, yet dependent on it. ${ }^{7 \mathrm{I}}$ Even where the linkages are not formally related to patron-client ties, civil society connections to domestic or international donors may take on a clientelistic quality that helps explain their privileged access to resources. Uneven as the results are, such informal forms of governance appear to hold considerably more promise than the frequently corrupt and largely discredited 'democratic' institutions put into place through elections. If so, the time has come to take seriously the criticisms advanced by a number of observers about the perverse consequences of a strategy of 'extraversion' based on the imperative of 'free and fair elections'. No less important in a context where ethnicity is a major challenge faced by local participatory structures is the need to better coordinate and strengthen donors' efforts to impose effective sanctions on Rwanda. This is not meant to downplay the responsibility of the Kabila government in contributing to the Congo's crisis, only to underscore what many seem to forget: that for the last twenty years, Rwanda has continually intervened in the internal affairs of the DRC, more often

69 S. Geenen, 'A dangerous bet: the challenges of formalizing artisanal mining in the Democratic Republic of Congo', Resources Policy, 37:3 (2012), 324.

70 Autesserre, 'Dangerous tales: dominant narratives on the Congo and their unintended consequences', African Affairs, III:443 (2OI2), 2 I2.

7I I am indebted to Oumar Sylla, Head of the Eastern office for UN-Habitat in DRC for alerting me to the large number of Kivu-based civil society organizations involved in mediation and participatory activities, including Centres de Médiation Communautaires (CDM) and Noyaux de Résolution des Conflits Fonciers (NRCF), as well as his assessment of the Comités Locaux Permanents de Conciliation (CLPC) operating under MONUSCO's supervision. For further information, see O. Sylla, 'Land and property disputes impeding return and reintegration', Forced Migration Review, 36 (Nov. 2010), I8-I9. 
than not with the direst consequences for the people of the Congo, including those it claimed to protect.

As the torch is passed on to new generations of scholars and students eager to discern the DRC's future, may they draw some of their inspiration from a proper reading of the region's tormented past. Such indeed is the aim of these reflections, offered in the hope that they can stimulate debate, challenge received ideas, and open up new vistas. 